\title{
Rethinking Aleister Crowley and Thelema
}

\author{
New Perspectives
}

\author{
Manon Hedenborg White \\ Södertörn University, Stockholm, Sweden \\ manon.hedenborg.white@sh.se
}

In recent decades, academic scholarship has increasingly recognised the British occultist, poet, and mountaineer Aleister Crowley (1875-1947) as a formative figure in the development of twentieth-century Western esotericism. Rejecting what he perceived as the repressive morals of his conservative, Christian upbringing, Crowley espoused a new religion centred on individual will, self-development, and liberation, which was heavily informed by the evolutionist perspectives that shaped late-nineteenth-century theories of religion as well as the occultism of his time. Openly bisexual at a time when consensual sexual acts between men were still criminalised, Crowley can be situated among sexual visionaries such as Edward Carpenter, Havelock Ellis, and D.H. Lawrence, who viewed erotic liberation as key to social transformation. Departing from the sensationalised narratives characterising media reports on Crowley during his lifetime, academic scholarship from the 199os on has, variously, addressed Crowley's life and thought in the context of VictorianEdwardian negotiations of sexuality and subjectivity; the transmission of Yoga to the West; and interwar political tensions, as well as a host of other topics. ${ }^{1}$ Through these scholarly lenses, Crowley appears in many ways as a distillation of the cultural tensions and tendencies of his time.

The details of Crowley's life and magical career have been extensively explored elsewhere, but bear brief recapitulation. ${ }^{2}$ Growing up in the dispensationalist, Evangelical movement the Plymouth Brethren, Crowley rebelled

1 E.g., Urban, Magia Sexualis; Owen, Place of Enchantment; Pasi, Aleister Crowley and the Temptation of Politics.

2 The most influential Crowley biographies to appear in recent years are Booth, A Magick Life; Sutin, Do What Thou Wilt; and Kaczynski, Perdurabo, of which the latter is generally considered the authoritative treatment. 
against his upbringing at an early age, identifying himself with the Great Beast 666 of Revelation. He joined the Hermetic Order of the Golden Dawn in 1898 and rose quickly through the grades. Though Crowley's involvement with the Golden Dawn ended in 19oo, its degree structure and magical curriculum came to comprise one of two basic components of his system of Magick, the second consisting of yogic techniques he learned while travelling in India, Burma, and Ceylon. ${ }^{3} 1904$ marked a turning point in Crowley's occult career. On honeymoon in Cairo, Crowley sought to impress his wife Rose (née Kelly, 18741932) with some invocations, when she entered a trance state, proclaiming that someone awaited him. This someone was later identified as the god Horus. At Rose's behest, Crowley over the course of April 8-10 penned The Book of the Law, which he claimed was dictated to him by a discarnate entity named Aiwass. ${ }^{4}$ The text announces the advent of a new epoch in the spiritual evolution of humanity, with Crowley, as the Beast, as its prophet. This new age was to be characterised by individual liberation and self-realisation, epitomised by the maxim: 'Do what thou wilt shall be the whole of the Law', and the word Thelema (Greek for "will"), which became the title of Crowley's religion. ${ }^{5}$

Crowley's magical teachings were structured within two initiatory orders. The first of these was A.:A.:, which Crowley co-founded with George Cecil Jones (1873-1960) in 1907, and whose curriculum combined ceremonial magic in the style of the Golden Dawn with yogic techniques and study of the "Holy Books of Thelema". ${ }^{6}$ The second order within which Crowley assumed a formative role was Ordo Templi Orientis (ото), an initiatory fraternity led by the German socialist and singer Theodor Reuss (1855-1923). ото claimed to possess the secret uniting all masonic and Hermetic systems, namely, that of sexual magic. ${ }^{7}$ Reuss made Crowley the head of ото in Britain in 1912, and from 1914 onward, he began experimenting systematically with sexual magic. Over time, he came to reshape ото's degree structure and rituals in accordance with Thelema, assuming international headship of the order after Reuss's death. ${ }^{8}$

3 For Crowley's elaboration of his magical system, see, e.g., Crowley, Magick: Liber ABA. For a brief introduction to Crowley's Thelema and system of Magick, see Bogdan, 'Aleister Crowley: A Prophet for a Modern Age'.

4 The events leading up to Crowley's reception of The Book of the Law are described in Crowley, The Equinox of the Gods.

5 See Crowley, The Book of the Law.

6 See Crowley, $\Theta E \Lambda H M A$. For Crowley's condensed exposition of the A.:A.: system, see 'One Star in Sight', in Crowley, Magick: Liber ABA, 479-489.

7 Reuss, I.N.R.I./Jubilceums-Ausgabe der Oriflamme.

8 For Crowley's record of his early sex magical experiments, see e.g., the magical diary 'Rex de Arte Regia' from 1914-1918, published in Crowley, The Magical Record of the Beast 666, 1-82. 
After spending the wwI-years in the U.S., Crowley returned to Europe, where he established an "Abbey of Thelema" at Cefalù, Sicily, in 1920, together with his lover and disciple Leah Hirsig (1883-1975). Over the following years, several of Crowley's disciples would periodically reside at the Abbey. However, a series of scandals prompted Crowley's expulsion from Italy by order of Mussolini in 1923, and the commune died out a few years later. ${ }^{9}$

Crowley's A.:A.: and ото had few members during his lifetime, and his publications generally had modest distribution, including his introductory textbook Magick in Theory and Practice (1929), and his work on the tarot, The Book of Thoth (1944), born from more than two decades of Crowley wanting to craft a tarot deck of his own..$^{10}$ In the years after Crowley's death in 1947, ото was more or less inactive, though broader interest in his life and works was, to some extent, perpetuated with the publication of a polemical biography by Crowley's literary executor, John Symonds (1914-2006). ${ }^{11}$

1969 witnessed the reconstitution of ото by a group of California Thelemites, led by Grady Louis McMurtry (1918-1985). Wider interest in Crowley's works was also revitalised in the late 1960s and early 1970s by the publication efforts of his former secretaries Israel Regardie (1907-1985) and Kenneth Grant (1924-2011), the latter working in collaboration with Symonds. ${ }^{12}$ Coinciding with the countercultural movement and the so-called sexual revolution, Crowley's liberal views on drugs gained him the status of a minor icon, epitomised by his famous appearance on the cover of The Beatles' Sgt. Pepper's Lonely Hearts Club Band (1967). The largest Thelemic organisation today is ото, which counts

Crowley's reformulation of the ото's degree system and sexual magic is discussed in Bogdan, 'Challenging the Morals of Western Society'. The early history of ото is explored in detail in Kaczynski, Forgotten Templars. For a brief overview of the order's trajectory, see Pasi, 'Ordo Templi Orientis'; Giudice, 'Ordo Templi Orientis'.

9 See Crowley, Magical Record of the Beast 666; Crowley, Confessions, 863-883; 912-922, passim. Crowley's sex magical experiments at the Abbey of Thelema are analysed in Hedenborg White, The Eloquent Blood, 94-107 as well as in Kaczynski, 'Taboo and Transformation in the Works of Aleister Crowley'.

10 Crowley had been interested in creating his own tarot from at least 1920, as evinced by the discovery of artwork he created at the Abbey of Thelema. See Pasi, 'Aleister Crowley, Painting, and the Works from the Palermo Collection'.

11 Symonds, The Great Beast.

12 Examples of works edited and introduced by Regardie include Crowley, AHA (1969); Crowley, The Vision and the Voice (1972); and Crowley, Magick without Tears (1973); examples of works edited and introduced by Grant and Symonds include Crowley, Confessions (1969); Crowley, The Magical Record of the Beast 666 (1972); and Crowley, Magical and Philosophical Commentaries on the Book of the Law (1974). 
around 4,0oo members worldwide. ${ }^{13}$ However, an accurate measure of Crowley's impact on the landscape of late-modern esotericism will not only account for the number of self-identified Thelemites, but also for Crowley's formative influence on late-modern sexual magic, Wicca, Satanism, and Chaos Magick, as previous research has demonstrated..$^{14}$

Within academia, Crowley's ideas, legacy, and followers have principally been studied by scholars of Western esotericism, exemplifying the field's propensity for revaluating and bringing attention to hitherto neglected or 'rejected' historical figures, groups, and intellectual currents. ${ }^{15}$ Academic interest in Crowley began in earnest in the 1990s. ${ }^{16} 1997$ marked the conference 'Un mago a Cefalù. Aleister Crowley e il suo soggiorno in Sicilia', held in Cefalù, Sicily, and resulting in the publication of a proceedings volume edited by PierLuigi Zoccatelli the following year. ${ }^{17}$ The year 1997 also witnessed the publication of an article by Alex Owen treating Crowley's exploration of the self as an engagement with Edwardian subjectivity and its complex dynamics of gender, race, and colonialism. ${ }^{18}$ Marco Pasi's Aleister Crowley e la tentazione della politica (published in English in 2014), first appearing in 1999, is the earliest scholarly monograph focused entirely on Crowley and explores his relationship with politics. ${ }^{19}$ From outside of the academic study of esotericism, the 199os on have witnessed the publication of several major biographies on Crowley and some of his key disciples, as well as annotated editions of Crowley's writings. ${ }^{20}$

13 Cf. Hedenborg White, The Eloquent Blood, 195. For a brief overview of the contemporary ото, see Hedenborg White, 'Ordo Templi Orientis'.

14 See, e.g., Urban, Magia Sexualis, 109-139, passim; Bogdan, 'Challenging the Morals of Western Society'; Hutton, 'Crowley and Wicca'; Dyrendal, 'Satan and the Beast'.

15 Cf. Hanegraaff, Esotericism and the Academy.

16 Among the pioneering scholarly treatments of Crowley deserving of mention here, Introvigne, Il cappello del mago and Introvigne, Indagine sul satanismo, stand out.

17 Zoccatelli, Aleister Crowley: un mago a Cefalù.

18 Owen, 'The Sorcerer and His Apprentice'. This article was the basis for a chapter in Owen, The Place of Enchantment (186-220), as well as in Bogdan and Starr (eds.), Aleister Crowley and Western Esotericism (18-6o).

19 Pasi, Aleister Crowley e la tentazione della politica; Pasi, Aleister Crowley and the Temptation of Politics.

20 See footnote 2. Beyond these biographical works, substantial contributions to the understanding of Crowley and his ideas, as well as those of his later disciples, have come from persons working outside of the academic study of religion, and include both annotated editions of diaries and texts as well as biographical works that have laid the groundwork for further scholarship. These include, but are not limited to, Starr, The Unknown God; Kaczynski, Forgotten Templars; Giudice, Crowley: Early Poetic Works; and the large number of new editions of Crowley's works edited by Hymenaeus Beta, including, but not limited to, Crowley, Liber Aleph (1991); Crowley, Magick: Liber ABA (1994), Crowley, The Law is for 
In a 2003 essay, Marco Pasi suggested the time was ripe for a move away from a (by that point) 'neverendingly told story' (i.e., that of Crowley's life) to a 'search for as yet untold stories', implying more specialised treatments of particular aspect of Crowley's thought and legacy. ${ }^{21}$ This has increasingly been the tendency of later research, ${ }^{22}$ in which the publication of Aleister Crowley and Western Esotericism (eds. Henrik Bogdan and Martin P. Starr, 2012), is arguably a benchmark in the establishment of Crowley and Thelema within the academic study of Western esotericism. In the introduction, editors Bogdan and Starr observe that 'the abundant details of his [Crowley's] chronicled life tend to obscure the dominant trends in the development of his intellectual and spiritual topoi. ${ }^{23}$ The book addressed this lacuna by bringing together essays on a range of specialised topics including Crowley's influence on Wicca, Satanism, and Scientology; his approach to magical practice; and his indebtedness to the dispensationalist worldview of his Plymouth Brethren parents. Since, parallel sessions on Crowley have been held at the biennial conferences of the European Society for the Study of Western Esotericism (ESSWE) in 2013, 2017 and 2019. In recent years, scholars have directed attention to a number of remaining gaps in the study of Crowley and Thelema, such as the impact of South Asian spirituality including yogic and tantric teachings on Crowley's magical system; notions of gender within Crowley's thought as well as that of his later disciples; and the reception of Crowleyan magical rituals among present-day practitioners. ${ }^{24}$

The present volume, comprising five articles, continues to heed the call for more specialised research, while simultaneously breaking new ground in terms of the topics covered as well as the analytical lenses utilised. Henrik Bogdan's article 'Deus Est Homo: The Concept of God in the Magical Writings of the Great Beast 666 (Aleister Crowley)' addresses the concept of God in Crowley's magical oeuvre, arguing that Crowley epitomised the occultism of his time in his navigation of the problems of modernity, disenchantment, and disillusion-

All (1996); Crowley, Commentaries on the Holy Books and Other Papers (1996); and Crowley, The Vision and the Voice with Commentary and Other Papers (1998).

21 Pasi, 'The Neverendingly Told Story'.

22 An early example is Hugh B. Urban's usage of a Foucauldian lens to analyse Crowley's sexual magic in the context of late-nineteenth and early-twentieth-century anxieties surrounding sexuality, liberation, and transgression. Urban, Magia sexualis, 109-139.

23 Bogdan and Starr, 'Introduction', 6.

24 E.g., Djurdjevic, India and the Occult, 61-72; Djurdjevic, 'Wishing You a Speedy Termination of Existence'; Hedenborg White, 'To Him the Winged Secret Flame'; Hedenborg White, The Eloquent Blood; Lycourinos, Ritual Embodiment in Modern Western Magic. 
ment with organised religion in its established forms. Bogdan highlights how the concept of God has remained under-theorised within the study of esotericism in general, as well as within academic analyses of Crowley's writings, and brings attention to Crowley's complex and multifaceted understanding of divinity. In the article, Bogdan identifies five aspects of Crowley's concept of God as particularly significant: his childhood experiences of the Plymouth Brethren; the impact of empirical scepticism and comparative religion; the emanationist theology of the kabbalistic Tree of Life; the revelation of The Book of the Law and Crowley's self-assumed role as prophet of a new religion; and the 'solar-phallicism' of ото. An important contribution of the article is to show that the religious faith of Crowley's parents-despite Crowley's vocal rejection thereof-had a lingering impact on his magical worldview, which echoed the centrality ascribed to the study of holy scripture, the belief in a succession of spiritual aeons, and the idea of an interventionist God actively shaping human history.

While Bogdan's article takes an in-depth look at Crowley's magical writings, there is another aspect of the latter's written production that is no less important for understanding his legacy: poetry. Throughout his life, Crowley produced a substantial body of lyrical work ranging from romantic sonnets to war poems. In the article "It was your Wickedness my Love to Win": Towards an Appraisal of Aleister Crowley's Decadent Period (1895-1898)', Christian Giudice analyses Crowley's early poetry, situating Crowley within the Aesthetic and Decadent movements, and showing him to be strongly indebted to the works of Percy Bysshe Shelley (1792-1822), Sir Richard Burton (1821-189o), and Algernon Swinburne (1837-1909). Giudice notes that Crowley's poetry encapsulated central themes of the Decadent movement, including 'the exasperated sexuality, the morbid settings, the necessity to transcend nature and grasp the transcendental'. However, Giudice contends, Crowley's poetry came too late to benefit from the Decadent vogue of the early 189os, at which point Decadence was a declining movement in Britain-partly because of the conviction of Oscar Wilde, and partly because of the emergence of Modernist poetry. Proposing a re-evaluation of Crowley's place in literary history, Giudice argues that Crowley should be taken seriously as a late but genuine representative of British Decadence.

Manon Hedenborg White's article 'Proximal Authority: The Changing Role of Leah Hirsig in Aleister Crowley's Thelema, 1919-1930' surveys the life and role of the Swiss-American music teacher Leah Hirsig (mentioned above), who was Crowley's disciple, "Scarlet Woman", and second-in-command during the formative period 1920-1924. During this period, Hirsig co-founded the Abbey of Thelema in Cefalù, assisted Crowley in the production of numerous signifi- 
cant writings, presided over his initiation to the A.:A.: degree of Ipsissimus, and held governing positions within both A.:A.: and ото. After Crowley in September 1924 found a new Scarlet Woman, Hirsig's position in the Thelemic movement declined significantly, and she began distancing herself from Crowley in 1927. With Hirsig as a case study, Hedenborg White proposes the term 'proximal authority' (as an addition to Max Weber's tripartite typology), defined as authority ascribed to or enacted by a person based on their real or perceived closeness to a leader, using it as the starting point for discussing how relational closeness can both enable and condition a precarious form of leadership in new religious movements.

Two articles in this issue explore, from different viewpoints, the tarot; a welcome contribution as the Crowley-Harris Thoth Tarot is one of the most widely used tarot decks in circulation, yet an aspect of Crowley's legacy that has received limited scholarly attention. ${ }^{25}$ Matthew Fletcher's article 'The Cardinal Importance of Names: Aleister Crowley and the Creation of a Tarot for the New Aeon' examines Crowley's The Book of Thoth (1944), specifically his decision to change the traditional titles of tarot trumps VIII, XI, XIV, and XX. Fletcher explores the significance of these name changes as well as Crowley's motivations for making them, touching briefly on the iconographic treatment of the cards in question in the Crowley-Harris deck. Fletcher observes that Crowley's motivation for these name changes was his perception of tarot history, indebted to occultist interpretations of the tarot as an ancient repository of esoteric wisdom harkening back to Pharaonic Egypt. Arguing that Crowley perceived the "original" tarot to have undergone a degenerating, Christianising influence, Fletcher proposes that Crowley's motivation for the name changes was a wish to cleanse the tarot of Christian remnants in favour of the tenets of Thelema.

Finally, Deja Whitehouse's article "'Mercury is in a Very Ape-Like Mood": Frieda Harris's Perception of Thelema', hones in on the collaborative relationship that birthed the Thoth Tarot deck, namely, that of Crowley and the artist Frieda Lady Harris (1877-1962), whom Crowley commissioned to execute his designs for the cards. The article focuses on Harris' relationship to Thelema, and Whitehouse conducts a meticulous investigation of unpublished archival sources to trace the artist's involvement with Crowley's magical system and his orders A.:A.: and ото. Whitehouse's analysis shows Harris as a serious spiritual practitioner of varied interests, whose devotion to Crowley at some points jeop-

25 Exceptions include Farley, Cultural History of the Tarot, 137-142; Decker and Dummett, The History of the Occult Tarot. 
ardised her public standing and even her marriage. Whitehouse highlights how Harris' own magical trajectory informed her art, devoting particular attention to how Harris perceived and navigated her relationship with the deity Mercury, showing this to have exerted a direct influence on her artistic process, complicating her work on the Magus trump. In Whitehouse's exploration, Harris' relationship with Crowley's system of Magick and religion Thelema emerges as both earnest and complex, varying over time and lessening after Crowley's death in favour of other spiritual pursuits. Nevertheless, Whitehouse indicates Harris' enduring devotion to Crowley's cause.

As guest-editor, I have endeavoured to bring together the perspectives of both established and emerging scholars whose novel approaches should not only be of interest to Crowley specialists, but also to scholars and students within the broader study of (Western) esotericism. Bogdan's and Giudice's articles situate Crowley's writings - magical and lyrical, respectively—within broader cultural movements at their time, while Hedenborg White's article shows how patterns of authority discerned in other new religious movements were also evident among the early Thelemites. Fletcher's and Whitehouse's contributions show (perhaps paradoxically) both the importance of Crowley's Thelema to a tarot deck used by thousands of non-Thelemites, and the impact of an artist with an ambivalent relationship to Thelema on the creation of one of the most famous aspects of Crowley's legacy. It is also worth highlighting the fact that two of the articles in this special issue have as their main focus women who were connected to Crowley. Previous scholarship has shown that many fin-de-siècle occult orders offered considerable opportunities for female leadership, though less has been written about the women in the early Thelemic movement-with several scholars instead stressing the sexism (at least by contemporary standards) evinced in some of Crowley's writings. ${ }^{26}$ As Whitehouse's and Hedenborg White's articles indicate, Crowley's caustic remarks against women both in general and in particular belie more complex dynamics of gender within the early Thelemic movement, in which several women held key roles both during Crowley's lifetime and after. ${ }^{27}$

26 Examples of works tracing the roles of women in fin-de-siècle occultism include, but are not limited to, Dixon, Divine Feminine; Owen, The Darkened Room; Braude, Radical Spirits; Greer, Women of the Golden Dawn. The notion of sexism in Crowley's writings has been raised in, among others, Owen, 'The Sorcerer and His Apprentice'; Urban, Magia Sexualis, 134-135.

27 Cf. Hedenborg White, The Eloquent Blood, 111-112. The role of women in the Thelemic movement is the subject of a forthcoming anthology from Kamuret Press, see Hedenborg White and Giudice, Women of Thelema: Selected Essays. 
In conclusion, I would like to take the opportunity to issue some thanks. Firstly, to Dr Egil Asprem, editor-in-chief of Aries, for allowing the opportunity to curate this special issue and for offering his assistance, insight, and patience throughout the process. Secondly, considerable gratitude is extended to each of the anonymous peer-reviewers who, despite a tight production schedule, offered feedback and constructive comments on each of the essays included in this volume. Finally, though the articles herein highlight several novel ways of understanding Aleister Crowley and his legacy, they by no means represent the end of the road for scholarship in this area. For instance, all articles in this issue draw on historical and/or philological methods. An important avenue for continued future research is sociological and ethnographic studies of the contemporary magical milieu in which Crowley's ideas and organisations still play an important role; an area in which some work has already been undertaken, but much remains. In other words, the search for as yet untold stories continues.

\section{Bibliography}

Bogdan, H., 'Aleister Crowley: A Prophet for a Modern Age', in: Partridge, C. (ed.), The Occult World, 293-302, New York: Routledge 2015.

Bogdan, H., 'Challenging the Morals of Western Society: The Use of Ritualized Sex in Contemporary Occultism', The Pomegranate 8:2 (2006), 211-246.

Bogdan, H., and M.P. Starr (eds.), Aleister Crowley and Western Esotericism, New York: Oxford University Press 2012.

Bogdan, H., and M.P. Starr, 'Introduction', in Bogdan, H. and Starr, M.P., Aleister Crowley and Western Esotericism, 3-13, New York: Oxford University Press 2012.

Booth, M., A Magick Life: The Biography of Aleister Crowley, London: Hodder \& Stoughton 2000 .

Braude, A., Radical Spirits: Spiritualism and Women's Rights in Nineteenth-Century America, Boston: Beacon Press 1989.

Crowley, A., Magick: Liber ABA, ed. Hymenaeus Beta, York Beach: S. Weiser 1994.

Crowley, A., The Book of the Law: Liber Alvel Legis: With a Facsimile of the Manuscript as Received by Aleister and Rose Edith Crowley on April 8, 9, 10, 1904 E.v. Centennial Edition, York Beach: Red Wheel/Weiser 2004.

Crowley, A., The Confessions of Aleister Crowley: An Autohagiography, London: Arkana 1989.

Crowley, A., The Equinox of the Gods, London: ото 1936.

Crowley, A., The Magical Record of the Beast 666: The Diaries of Aleister Crowley 19141920, ed. J. Symonds and K. Grant, Montreal: 93 Publishing 1974. 
Crowley, A., $\Theta E \Lambda H M A$ [Thelema], London: privately printed $19 \circ 9$.

Decker, R., and M. Dummett, The History of the Occult Tarot, 1870-1970, London: Duckworth 2002.

Dixon, J., Divine Feminine: Theosophy and Feminism in England, Baltimore, MD: Johns Hopkins University Press 2001.

Djurdjevic, G., 'Wishing You a Speedy Termination of Existence: Aleister Crowley's Views on Buddhism and Its Relationship with the Doctrine of Thelema', Aries:Journal for the Study of Western Esotericism 19:2 (2019), 212-230.

Djurdjevic, G., India and the Occult: The Influence of South Asian Spirituality on Modern Western Occultism, New York: Palgrave Macmillan 2014.

Dyrendal, A., 'Satan and the Beast: The Influence of Aleister Crowley on Modern Satanism', in: Bogdan, H., \& Starr, M.P. (eds.), Aleister Crowley and Western Esotericism, 369-394.

Farley, H., A Cultural History of Tarot: From Entertainment to Esotericism, London: I.B. Tauris 2009 .

Giudice, C., 'Ordo Templi Orientis', in: Partridge, C. (ed.), The Occult World, 277-282, Oxon: Routledge 2015 .

Giudice, C., Aleister Crowley: Early Poetic Works, London: Kamuret Press 2020.

Greer, M.K., Women of the Golden Dawn: Rebels and Priestesses, Rochester: Park Street Press 1995 .

Hanegraaff, W.J., Esotericism and the Academy: Rejected Knowledge in Western Culture, Cambridge: Cambridge University Press 2012.

Hedenborg White, M. 'To Him the Winged Secret Flame, To Her the Stooping Starlight: The Social Construction of Gender in Contemporary Ordo Templi Orientis', The Pomegranate: International Journal of Pagan Studies 15:1-2 (2013), 102-121.

Hedenborg White, M., 'Ordo Templi Orientis', in: Asprem, E. (ed.), Dictionary of Contemporary Esotericism, Leiden: Brill [forthcoming].

Hedenborg White, M., and C. Giudice, (eds.), Women of Thelema: Selected Essays, London: Kamuret Press [forthcoming].

Hedenborg White, M., The Eloquent Blood: The Goddess Babalon and the Construction of Femininities in Western Esotericism, New York: Oxford University Press 2020.

Hutton, R., 'Crowley and Wicca', in: Bogdan, H., \& Starr, M.P. (eds.), Aleister Crowley and Western Esotericism, 285-306, New York: Oxford University Press 2012.

Introvigne, M., Il cappello del mago: I nuovi movimenti magici, dallo spiritismo al satanismo, Milan: Sugarco 1990.

Introvigne, M., Indagine sul satanismo: Satanisti e anti-satanisti dal seicento ai nostri giorni, Milan: Mondadori 1994.

Kaczynski, R., 'Taboo and Transformation in the Works of Aleister Crowley', in: Hyatt, C.S. (ed.), Rebels \& Devils: The Psychology of Liberation, 3rd ed., Tempe: The Original Falcon Press 1996. 
Kaczynski, R., Forgotten Templars: The Untold Origins of Ordo Templi Orientis, n.p.: R. Kaczynski 2012.

Kaczynski, R., Perdurabo: The Life of Aleister Crowley, and ed., Berkeley: North Atlantic Books 2010.

Lycourinos, D.Z., Ritual Embodiment in Modern Western Magic: Becoming the Magician, New York: Routledge 2017.

Owen, A., 'The Sorcerer and His Apprentice: Aleister Crowley and the Magical Exploration of Edwardian Subjectivity', Journal of British Studies 36 (1997), 99-133.

Owen, A., The Darkened Room: Women, Power and Spiritualism in Late Victorian England, London: Virago 1989.

Owen, A., The Place of Enchantment: British Occultism and the Culture of the Modern, Chicago: University of Chicago Press 2004.

Pasi, M., 'Aleister Crowley, Painting, and the Works from the Palermo Collection', Abraxas: International Journal of Esoteric Studies 3 (2015), 65-77.

Pasi, M., 'Ordo Templi Orientis', in: Hanegraaff, W.J., et al. (eds.), Dictionary of Gnosis and Western Esotericism, 898-9o6, Leiden: Brill 2005.

Pasi, M., 'The Neverendingly Told Story: Recent Biographies of Aleister Crowley', Aries 3:2 (2003), 224-245.

Pasi, M., Aleister Crowley and the Temptation of Politics, Durham: Acumen 2014.

Pasi, M., Aleister Crowley e la tentazione della politica, Milan: FrancoAngeli 1999.

Reuss, T., ed. I.N.R.I./Jubilceums-Ausgabe Der Oriflamme, Berlin; London: privately printed, 1912.

Starr, M.P., The Unknown God: W.T. Smith and the Thelemites, Bolingbrook: Teitan Press 2003.

Sutin, L., Do What Thou Wilt: A Life of Aleister Crowley, New York: St. Martin's Press 2000. Symonds, J., The Great Beast: The Life of Aleister Crowley, London: Rider 1951.

Urban, H.B., Magia Sexualis: Sex, Magic, and Liberation in Modern Western Esotericism, Berkeley: University of California Press 2006.

Zoccatelli, P., Aleister Crowley: un mago a Cefalù, Rome: Edizioni Mediterranee 1998. 